\title{
Erik's Effects: The Phantom, the Gesamtkunstwerk and the Monstrosity of Spectacle
}

\author{
Ivan Phillips
}

\begin{abstract}
Virginia Woolf famously dated the origins of the modern sensibility to December 1910. This chapter, using the idea of the Gesamtkunstwerk or 'total work of art' as its theoretical starting point, argues that Gaston Leroux's The Phantom of the Opera, published in the same year, represents a distinct product of this sensibility. Enacting a compelling narrative of 'monstrous' unsettlement within mass culture, the novel is one of the iconic monster fictions of the twentieth century, although it continues to be critically neglected compared to similar literary horror classics. The Opera Ghost, Erik, a grotesque social outcast, is a special effects artist on a grand scale, a fairground magician and inspired architect as well as a torturer, assassin and psychotic obsessive. Beneath the Palais Garnier he creates a world of trapdoors, pulleys and costumes, of smoke and mirrors, of flame effects and water, creating a Gesamtkunstwerk within a Gesamtkunstwerk. His legacy is a troubled, prophetic and inexhaustible allegory of emergent modernity, in particular of mass media spectacle and shared popular fantasy. As charismatic as he is terrifying, as tragic as he is cruel, this beast in search of beauty seems to embody both the fear and the fascination of a complex mediated environment. Ultimately, the spaces he inhabits offer singular perspectives from which to explore the cultural conditions of the last hundred years.
\end{abstract}

Key Words: Gothic, monstrosity, media, interface, Gesamtkunstwerk, Leroux, Lessing, laocoönism, spectacle, modernity.

$* * * * *$

This is a kind of ghost story, tracing the spectre of a familiar, perhaps too familiar, modern myth through the echoing architecture of an idea. The story begins in 1910, a year in which three things happened that might be seen as establishing the critical coordinates for this chapter. Irving Babbitt published The New Laokoön: An Essay on the Confusion of the Arts, Gaston Leroux published Le Fantôme de l'Opéra and, according to Virginia Woolf's famous analysis, 'human character changed'. In other words, the earliest of several important and influential twentieth century polemics against the concept of the Gesamtkunstwerk or 'total work of art' coincided with one possible start date for European cultural Modernism and the appearance of one of the most powerful Gothic mythologies of the last century. 
Babbitt's book was written in reaction to the particular kind of Romanticism embodied, not unambiguously, in the ideal of unified creation championed most famously by the composer Richard Wagner in two essays of 1849, 'Art and Revolution' and 'The Art-Work of the Future.' ${ }^{, 2}$ The Gesamtkunstwerk is a dream (or, depending on your viewpoint, a nightmare) of artistic fusion which sets itself against the alternative principle of medium specificity articulated by G.E. Lessing in his work of 1766, Laocoön: An Essay on the Limits of Painting and Poetry. ${ }^{3}$ In one vision, the arts cohere in an expression of utopian cultural coherence and creative contiguity, in the other they are delimited by the pure and precise requirements of their distinct natures. For many, the archetypal Gesamtkunstwerk is Wagner's own opera house at Bayreuth, with its double proscenium and sunken orchestra, placing emphasis on illusions of space, presence, extreme mood lighting and sheer acoustic magnitude. Antecedents for this are the great mediaeval cathedrals of Europe, architectural mergings of work in stone, glass, metal, paint and sound. The idea can also be traced within the phantasmagorical spectacles of Paul Philidor and Étienne-Gaspard Robert in the late eighteenth and early nineteenth centuries, stage-crafted, often site-specific, orchestrations of paint-work, model-work and glass-work, visual and sonic projection, live performance and live effects in smoke, flame and water. Today, we would look no further than fairground rides at Alton Towers, Thorpe Park and elsewhere, or the theme parks of Disney, The Making of Harry Potter, the Doctor Who Experience and so on.

It is easy to forget that Wagner's notion of the total work of art has its origins in a revolutionary utopianism which, as Sven Lütticken has written, 'aimed not only at uniting the arts, but also at integrating art and society once again,' reviving the sense, embodied in those mediaeval cathedrals, of 'a place where individual people became an organic whole of believers'. ${ }^{4}$ The social idealism of this is eroded by Wagner's notorious anti-Semitism and by his reputation as the composer of choice for Nazism. It is further worn away by more recent scepticism about the 'commercial gesamtkunstwerk' ${ }^{5}$ and the broader social effects of complex immersive spectacle on audiences. The ideological shadow cast over the concept of the total work of art has been captured well by Juliet Koss:

Loosely associated with synaesthesia, phantasmagoria, and psychedelia, the term Gesamtkunstwerk often stands for an artistic environment or performance in which spectators are expertly maneuvered into dumbfounded passivity by a sinister and powerful creative force. It is often mistaken for a hazy mixture of art forms that intoxicates those who gather in its presence, encouraging the kind of passive aesthetic response also ascribed to the spectacle culture famously articulated by Guy Debord in $1968 .^{6}$ 
Seen as industrialised and manipulatively commercial (it 'overwhelms the spectators' emotions, impedes the possibility of critical thought, and moulds a group of individuals into a powerless mass' $)^{7}$ rather than spiritually edifying and socially cohesive, the Gesamtkunstwerk has become seriously tainted as an ideal of the socially inclusive art form. So, after Babbitt come Rudolf Arnheim, Clement Greenberg, Nöel Carroll, Rosalind Krauss and others. ${ }^{8}$ Most damagingly, the concept has been scarred by its embroilment in Theodor Adorno's analysis of the 'relapse into barbarism' leading up to the Second World War and by its apparent manifestation of a romantically sensationalist anti-Modernism. ${ }^{9}$ However, the last twenty years has seen a revision of critical opinion in relation to experiences of immersive, hybrid and collective mass media. Lev Manovich has not been alone in proclaiming the beginning of the 'post-media age,' an age in which '[v]arious cultural and technological developments have together rendered meaningless one of the key concepts of modern art - that of a medium. ${ }^{10}$ After all, most people now carry a kind of miniature Gesamtkunstwerk about their person in the form of a smartphone, tablet computer and/or laptop, and as Douglas Kellner has commented 'spectacle itself is becoming one of the organizing principles of the economy, polity, society, and everyday life. 11

The aim of this chapter is to assert that Leroux's Le Fantôme de l'Opéra, translated into English within a year of its initial publication, constitutes a powerful and complex reading of the concept of the total work of art at a time of immense cultural change and uncertainty. In the character of Erik, the Opera Ghost, Leroux created one of the great mythic figures of modernity. This spectral, deathly, obsessed and twisted genius, whispering to the young singer Christine Daae in the shadows of the Paris Opera House, is a deeply troubling character in his elusiveness, in his threat, in his tragedy, in his charisma, but perhaps most of all in his brilliance. Erik the Phantom is, whatever else he might be, a special effects artist par excellence. Five storeys beneath the Palais Garnier, he has created his own spectacular and deadly theme park comprising trap-doors, mirrors, flame effects, water features, shock tactics, torture chambers and a suburban house on a lake. In the foundations of a great public building exemplifying the spectacular mutuality of the nineteenth century architecture, interior design, music, stonework, lighting, sculpture, painting, he has created a secret kingdom of fantasy. He has created a Gesamtkunstwerk within a Gesamtkunstwerk.

Born near Rouen, the son of a master mason, Erik is rejected as a child because of his great ugliness. Fleeing home, he finds himself travelling Europe and the Middle East from fair to fair, originally as part of a freak-show, displayed in 'all his hideous glory,' but gradually developing into a renowned singer, a conjuror, a ventriloquist, a special effects practitioner, 'complet[ing] his strange education as an artist and magician at the very fountainhead of art and magic, among the gypsies. ${ }^{12} \mathrm{He}$ is taken into the employ of the Persian Shah at Mazenderan, creating distractions for the bored sultana and a dwelling through which her paranoid father 
is able to move unseen: 'Erik had very original ideas on the subject of architecture and thought out a palace much as a conjuror contrives a trick casket. ${ }^{, 13} \mathrm{He}$ later transfers his skills to the Sultan of Constantinople, constructing the trap-doors, secret chambers and strong-boxes of his palace at Yildiz-Kiosk. His technical ingenuity extends to engineering decoys for the imperilled ruler:

He also invented those automata, dressed like the Sultan and resembling the Sultan in all respects, which made people believe that the Commander of the Faithful was awake at one place when, in reality, he was asleep elsewhere. ${ }^{14}$

Both the Shah and, it is implied, the Sultan use Erik's 'diabolical inventive powers' to 'calmly' carry out 'political assassinations' and we are told that he is 'guilty of not a few horrors, for he seem[s] not to know the difference between good and evil., 15

This amoralism is profoundly emblematic of the phantom's character. He is a man whose inventiveness enables him to both kill without scruple and to simulate life with an uncanny verisimilitude. The nature of Erik's ugliness is significant here. In many adaptations of Leroux's story, his deformity is explained as the result of a tragic accident, usually fire or acid, but in the original novel and in the earliest film version it is clear that Erik is born as a horror. More specifically, he is born dead. In his early days in the travelling fairs and circuses he is exhibited as a 'living corpse' ${ }^{16}$ and in the famous unmasking scene it is as dead thing that he memorably characterises himself to Christine:

"Your hands! Your hands! Give me your hands!" And he seized my hands and dug them into his awful face. He tore his flesh with my nails, tore his terrible dead flesh with my nails!... "Know," he shouted, while his throat throbbed and panted like a furnace, "know that I am built up of death from head to foot and that it is a corpse that loves you and adores you and will never, never leave you!" 17

Yet Erik defies death at the same time as embodying and enacting it. Knowing too much, he is targeted for assassination by both the Shah and the Sultan. On each occasion he escapes, the first time with the help of the Persian daroga, being substituted by a rotted, half-eaten cadaver washed up on a beach and dressed in his clothes. The narrative never reveals how he survives the Sultan but it is almost as if, being death itself, he is incapable of dying. Not surprisingly, perhaps, he is revealed to sleep in a coffin.

Following his escape from the Sultan, Erik takes cover in plain commercial building work, 'becom[ing] a contractor like any other contractor, building 
ordinary houses with ordinary bricks. ${ }^{18}$ It is in this role that he becomes involved in the groundwork for the Palais Garnier:

When he found himself in the cellars of the enormous playhouse, his artistic, fantastic, wizard nature resumed the upper hand. Besides, was he not as ugly as ever? He dreamed of creating for his own use a dwelling unknown to the rest of the earth, where he could hide from man's eyes for all time. ${ }^{19}$

When Christine first visits Erik's underground lair, she notes that, although the heart of his dwelling is 'a drawing-room quite as commonplace as any,' it has one striking peculiarity: '[T] here was no mirror in the whole apartment. ${ }^{20}$ Given the phantom's grotesque appearance, this absence perhaps seems natural enough, but also suggests an interesting link between his condition and that of the vampire in Bram Stoker's Dracula. Where the phantom avoids mirrors because (presumably) he does not want to see his reflection, the Count avoids them because he has no reflection. ${ }^{21}$ Yet mirrors are a vital part of the thematic apparatus of Leroux's novel, most especially in the episode which sees the daroga and the Vicomte de Chagny trapped in the hexagonal torture chamber within Erik's apartment. This room, lined with mirrors, is based on an earlier version built as a 'palace of illusion ${ }^{22}$ for the sultana, but subsequently developed into a space of torment and execution. It is electrically lit and capable of being heated to intolerable temperatures. Effectively, it is a diorama that manufactures slow death by simulated desert heat. A 'great mirror' is also, of course, the station at which Christine hears the educating voice of the Angel of Music in her dressing-room, a point of exit and entrance for the Angel's alter ego, Erik the Opera Ghost. ${ }^{23}$

Mirrors are interfaces. They are sites where one thing meets another, or seems to meet another, sites of translation and feedback, where $x$ is able to feel the presence of $y$ and, more importantly, enjoy the illusion of contact with $y$, or even of becoming $y$. This is suggestive in relation to Erik, because his enigma as a character seems to be predicated on his distinctive relationship with interfacial points. Again sharing something of the liminal ontology of the vampire, he is a creature of ambivalence, a haunter of thresholds and dweller on the margins, impatient of windows and doors, effectively invisible to mirrors, but found wherever connection is implied. Erik is the voice from behind Christine's mirror, the red ink on the letters sent to the Opera House managers, the unseen presence in the room, on the stairs, on the rooftop, the life in death and death in life. Perhaps most powerfully his own personal interface, his skin, is a locus of manifest ambiguity. He wears a mask, both an extension (in McLuhanesque terms) of his own face and a concealment of it. ${ }^{24}$ The mask resembles a skull and the face 
beneath the mask resembles a mask that resembles a skull. After the unmasking, Erik asserts this paradox to the horrified Christine:

Then he hissed at me, "Ah, I frighten you, do I?... I dare say!... Perhaps you think that I have another mask, eh, and that this... this... my head is a mask? Well," he roared, "tear it off as you did the other!",

As Jerrold E. Hogle notes, in his study The Undergrounds of the Phantom of the Opera, this is an ambiguity that is lessened or erased in almost all of the adaptations of Leroux's novel. ${ }^{26}$ Even so, it is an ambiguity which hints at the power of this myth to offer both a critique and a celebration of the concept of the Gesamtkunstwerk.

As the demon at the heart of opera house, half-seen, ever-present, never-quitethere, Erik most obviously tempts towards an endorsement of negative readings of the total work of art. Death haunts the opera house literally and perhaps most emblematically in the moment when Erik sends the chandelier crashing down onto the audience, and in the disrupted locus of this great cultural wonderwork, the Palais Garnier, this might be seen as a metaphorical haunting of modernity itself. Gaston Leroux, we should remember, had made his living as a distinctly twentieth century journalist before turning to fiction, writing reports, for instance, from the Russian Revolution of 1905. Newspaper reports are an important part of the narrative fabric of The Phantom of the Opera and perhaps it is not surprising that in this, four years before the mechanised carnage of the First World War, it is possible to identify the spectre at the gathering feast of modern mass mediated culture. Stated plainly, does Erik the Phantom represent a deathly terror of the emerging modern world?

Unsettlement is a key idea here, and it can be related closely to the changing nature of the media interface. In particular, it can be observed that all media, when new, seem to undergo a period of unsettlement or radical instability, which is typified by formal self-consciousness and experimentation. The early years of the printing press, of the novel, of photography, of cinema, of the computer, all provide evidence of this. An initial period of creative openness and cultural uncertainty is followed by absorption into a 'mythic' (in the Barthesian sense of the word) world-view, characterised by more settled and comfortable processes of narration, representation, reception. ${ }^{27}$ Once a medium has been culturally assimilated, the restless energies of its inception are diverted into marginal practices which nevertheless inform and, at times of major political or cultural change, challenge the mainstream. One of the persistent myths of modernity is that the media of the past (unlike those of the present) were always stable, settled, known, welcomed, understood. Erik, constantly embodying resistance at the interfaces of the opera house, conveys an awareness that this state of settled grace 
was never the case. He is, after all, a profoundly unsettled creature. Clearly, he is a frightening figure, but he is also a sympathetic one. That is why, as with Frankenstein's Creature, as with Jekyll and Hyde, as with Dracula, his myth has endured. In Leroux's novel the Persian describes Erik as 'a real monster' but insists that he is

also, in certain respects, a regular child, vain and self-conceited and there is nothing he loves so much as, after astonishing people, to prove the really miraculous ingenuity of his mind' ${ }^{28}$

It is through his childlike innocence and capacity to astonish in ingenious ways that the Phantom of the Opera has found a permanent place in cultural consciousness. In this way, he can be seen as not only registering the apprehension and shock of the new, but also its excitement, its variety and its tantalising unpredictability.

\section{Notes}

${ }^{1}$ Virginia Woolf, 'Mr Bennett and Mrs Brown', Collected Essays, I (London: Hogarth Press, 1966), 320; Irving Babbitt, The New Laokoon: An Essay on the Confusion of the Arts (Boston and New York: Houghton Mifflin, 1910); Gaston Leroux, Le Fantôme de l'Opéra (Paris: Pierre Lafitte, 1910). The first, and until 1990 the only English translation, was by Alexander Teixiera de Mattos (London: Mills and Boon, 1911).

${ }^{2}$ For an exploration of Wagner and the Gesamtkunstwerk, see Matthew Wilson Smith, The Total Work of Art: From Bayreuth to Cyberspace (London: Routledge, 2007).

${ }^{3}$ Gotthold Ephraim Lessing, Laocöon, or The Limits of Painting and Poetry (London: Dent, 1930).

${ }^{4}$ Sven Lütticken, 'Undead Media,' Afterimage, 31.4 (January-February 2004): 12.

${ }^{5}$ Lütticken, 'Undead Media', 12.

6 Juliet Koss, 'The Myth of the Gesamtkunstwerk: Approaching Wagner's dumbfounding impact on modernity,' Der Tagesspiegel (14 September 2008), 2, accessed October 12, 2012. http://www.tagesspiegel.de/zeitung/the-myth-of-thegesamtkunstwerk/1323622.html

${ }^{7}$ Koss, 'The Myth of the Gesamtkunstwerk,' 1.

${ }^{8}$ Rudolf Arnheim, Film as Art (London: University of California Press, 1957), 199-230; Clement Greenberg, 'Towards a Newer Laocoon,' Partisan Review, 7 (July-August, 1940), 299-301; Rosalind Krauss, 'A Voyage on the North Sea': Art in the Age of the Post-Media Condition (London: Thames and Hudson, 2000); 
Nöel Carroll, 'The Specificity of Media in the Arts,' The Journal of Aesthetic Education, 19, 4 (Winter, 1985), 5-20.

${ }^{9}$ Theodor W. Adorno, Critical Models: Interventions and Catchwords (Chichester and New York: Columbia University Press, 2005), 191.

${ }^{10}$ Lev Manovich, 'Post-Media Aesthetics' (2001), Manovich.net, accessed October 12, 2012. http://manovich.net/articles/. Cf. Sven Lütticken, 'Undead Media,' Afterimage 31.4 (January-February 2004): 12-13.

${ }^{11}$ Douglas Kellner, 'Media Culture and the Triumph of the Spectacle,' Razón y Palabra, 39 (April-May 2004), accessed October 12, 2012. http://www.www.razonypalabra.org.mx/anteriores/n39/dkelner.html

${ }^{12}$ Gaston Leroux, The Phantom of the Opera, trans. Alexander Teixiera de Mattos (London: Wordsworth, 2008), p. 190. This is the truncated translation of 1910, which I have decided to use as it remains by far the best-known version of Leroux's novel in English. The centenary translation by Mireille Ribière is highly recommended, however, and presents the text in full (Harmondsworth: Penguin, 2009).

${ }^{13}$ Leroux, Phantom of the Opera, 190.

${ }^{14}$ Ibid.

${ }^{15}$ Ibid.

${ }^{16}$ Ibid.

${ }^{17}$ Ibid., 92 .

${ }^{18}$ Ibid.,191.

${ }^{19}$ Ibid.

${ }^{20}$ Ibid., 87, 90 .

${ }^{21}$ Bram Stoker, Dracula (London: Arrow, 1971), 26, 33. For further discussion of the mirror trope in vampire mythology, see Ivan Phillips, 'The Vampire in the Machine: Exploring the Undead Interface' and Sam George, "He make in the mirror no reflect": Undead Aesthetics and Mechanical Reproduction - Dorian Gray, Dracula, and David Reed's "vampire painting"", in Sam George and Bill Hughes, eds., Open Graves, Open Minds: Representations of Vampires and the Undead from the Enlightenment to the Present (Manchester: Manchester University Press, 2013), 290-316, 66-101.

${ }^{22}$ Leroux, Phantom of the Opera, 165.

${ }^{23}$ Ibid., 69, 108.

${ }^{24}$ In Marshall McLuhan's axiom 'the medium is the message', the medium is anything that extends the human, and its message is its social impact or effect rather than its informational content. See Marshall McLuhan, Understanding Media: The Extensions of Man (London and Cambridge, MA: MIT Press, 1994), 7. ${ }^{25}$ Leroux, Phantom of the Opera, 92. 
${ }^{26}$ Jerrold E. Hogle, The Undergrounds of the Phantom of the Opera: Sublimation and the Gothic in Leroux's Novel and its Progeny (Basingstoke: Palgrave Macmillan, 2003), 6.

${ }^{27}$ Roland Barthes, Mythologies, trans. Annette Lavers (London: Paladin, 1972). According to Barthes 'the very principle of myth' is that 'it transforms history into nature': 'it abolishes the complexity of human acts, it gives them the simplicity of essences' $(140,150)$.

${ }^{28}$ Leroux, Phantom of the Opera, 146.

\section{Bibliography}

\section{Primary Sources}

Leroux, Gaston. Le Fantôme de l'Opéra. Paris: Pierre Lafitte, 1910.

—. The Phantom of the Opera. London: Wordsworth, 2008.

- The Phantom of the Opera. Harmondsworth: Penguin, 2009.

Stoker, Bram. Dracula. London: Arrow, 1971.

\section{Secondary Sources}

Adorno, Theodor W. Critical Models: Interventions and Catchwords. Translated by Henry W. Pickford. Chichester and New York: Columbia University Press, 2005.

Arnheim, Rudolf. Film as Art. London: University of California Press, 1957. 199230 .

Babbitt, Irving. The New Laokoön: An Essay on the Confusion of the Arts. Boston and New York: Houghton Mifflin, 1910.

Barthes, Roland. Mythologies. London: Paladin, 1972.

Botting, Fred. Gothic. London: Routledge, 1996.

Carroll, Nöel. 'The Specificity of Media in the Arts.' The Journal of Aesthetic Education 19. 4 (Winter, 1985): 5-20. 
George, Sam, and Bill Hughes, eds. Open Graves, Open Minds: Representations of Vampires and the Undead from the Enlightenment to the Present. Manchester: Manchester University Press, 2013.

Greenberg, Clement. 'Towards a Newer Laocoön.' Partisan Review 7 (JulyAugust, 1940): 299-301.

Hogle, Jerrold E. The Undergrounds of the Phantom of the Opera: Sublimation and the Gothic in Leroux's Novel and its Progeny. Basingstoke: Palgrave Macmillan, 2003.

Jackson, Rosemary. Fantasy: The Literature of Subversion. London: Methuen, 1981.

Kellner, Douglas. 'Media Culture and the Triumph of the Spectacle.' Razón y Palabra 39 (April-May 2004). Accessed October 12, 2012. http://www.www.razonypalabra.org.mx/anteriores/n39/dkelner.html

Koss, Juliet. 'The Myth of the Gesamtkunstwerk: Approaching Wagner's dumbfounding impact on modernity.' Der Tagesspiegel (14 September 2008). Accessed October 12, 2012. http://www.tagesspiegel.de/zeitung/the-myth-of-thegesamtkunstwerk/1323622.html

Krauss, Rosalind. 'A Voyage on the North Sea': Art in the Age of the Post-Media Condition. London: Thames and Hudson, 2000.

Lessing, Gotthold Ephraim. Laocöon, or The Limits of Painting and Poetry. London: Dent, 1930.

Lütticken, Sven. 'Undead Media.' Afterimage 31. 4 (January-February 2004): 1213.

McLuhan, Marshall. Understanding Media: The Extensions of Man. London and Cambridge, MA: MIT Press, 1994.

Manovich, Lev. 'Post-Media Aesthetics'. Manovich.net. (2001) Accessed October 12, 2012. http://manovich.net/articles/ 
Smith, Matthew Wilson. The Total Work of Art: From Bayreuth to Cyberspace. London: Routledge, 2007.

Wagner, Richard. Prose Works: Vol. 1. London: Kessinger, 2007.

Woolf, Virginia. Collected Essays I. London: Hogarth Press, 1966.

Ivan Phillips is Associate Dean of School (Learning and Teaching) in the School of Creative Arts at the University of Hertfordshire. He is currently contemplating the links between technology, poetry and the Gothic and is also pondering a new theory of media which he intends to call 'unsettlement'. 